\title{
RÉTEGVONAL MENTI SZÁNTÁS DINAMIKAI SAJÁTOSSÁGAI
}

\section{THE DYNAMIC PARTICULARITIES OF CONTOUR PLOUGHING}

\author{
Pásztor Judit, ${ }^{1}$ Popa-Müller Izolda ${ }^{3}$ \\ Sapientia Erdélyi Magyar Tudományegyetem, Marosvásárhelyi Kar, Gépészmérnöki Tanszék, \\ Marosvásárhely, Románia \\ ${ }^{1}$ pjudit@ms.sapientia.ro \\ 2 ipmuller@ms.sapientia.ro
}

\begin{abstract}
The plough is the basic machine for soil work. It is usually connected to the tractor by means of a suspension system. The suspension system is a bar-shaped arm system fixed to the tractor frame, which fixes and raises the attached machine in three points. Its role is significant. Single-sided ploughing on slopes creates some special situations. This phenomenon was observed during a plowing competition and in this paper we look for solutions related to this topic.
\end{abstract}

Keywords: Ploughing, plough, contour line on slope, dynamics.

\section{Összefoglalás}

Az ágyeke a talajmegmunkálás alapmunkájának, a szántásnak az alapgépe. Az ágyeke az erőgéphez általában a hárompont-függesztő berendezés segítségével van kapcsolva. A függesztőszerkezet a traktor vázához rögzített, rudakból álló karrendszer, amely három pontban rögzíti és emeli a csatolt munkagépet. Szerepe jelentős. A lejtőn való szántás ágyekével néhány sajátos helyzetet teremt. Ezeket a jelenségeket egy szántóverseny alkalmával figyeltük meg, és erre keressük a válaszokat ebben a dolgozatban.

Kulcsszavak: szántás, ágyeke, rétegvonal, dinamika.

\section{Bevezetés}

A terepen való rétegvonal menti szántás megfigyelése során azt tapasztaltuk, hogy a barázda emelkedőre való fordítása során az erőgép járása nyugodtabb, az erőgép vezetője könnyen tartja az irányt. A barázda lefele való borítása során az erőgép vezetője nem tudja tartani az irányt, az erőgép nagyon nehezen kormányozható. A jelenséget egy szántóverseny során figyeltük meg, a legtöbb gépcsoportnál hasonló volt a helyzet. Erre a jelenségre kerestünk választ.

Valószínűsíthető, hogy a versenyen a versenyzők a lehető legjobb gépbeállítással és gépállapottal szántanak.
Feltételeztük, hogy a jelenséget a lejtőn való rétegvonal menti helyzetből származó új erők okozzák. Ezek az erők az erőgép-munkagép kapcsolatot megvalósító hárompont-függesztő berendezés által nyilvánulnak meg.

\subsection{A hárompont-függesztő berendezés és szerepe a függesztett munkagép üzemelte- tése során}

A hárompont-függesztő berendezés segítségével a munkagépet az erőgéphez kapcsolják.

Szerepe van az erőgép-munkagép gépcsoport üzemeltetésében, a vontatásban, a vonóerő nö- 
velésében, és általa a csatolt munkagép néhány fontos beállítása is megtörténik.

A hárompont-függesztő berendezés részei egy karrendszer és egy emelőszerkezet.

A karrendszer alapját két alsó vonókar (1) képezi. Ehhez csatlakozik két függesztőrúd (2) és két emelőkar (3). Ez utóbbiakat a (4) emelőtengely köti össze. A szerkezet része az (5) felső támasztórúd. Az alsó vonókarokhoz a (6)-os feszítőelemek rögzülnek (1. ábra).

Az emelőszerkezet részei a hidraulikaszivattyú, vezérlőszelep és egy hidraulikus munkahenger. A munkahenger elforgatja a 4-es emelőtengelyt.

A hárompont-függesztő berendezés egy térbeli karos mechanizmusnak tekinthető (2. ábra). A függesztő berendezés feladata egytengelyesíteni az erőgép-munkagép gépcsoportot.

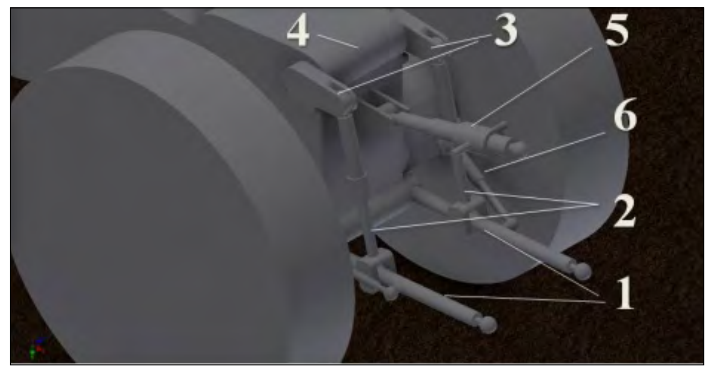

1. ábra. A hárompont-függesztő berendezés felépítése
Az alsó vonókarok traktor eleje irányában való meghosszabbításai a PFH pontban metszik egymást, ez a vízszintes pillanatnyi forgáspont (2. ábra). Javasolt, hogy a PFH vízszintes pillanatnyi forgáspont a traktor középvonalában legyen. A feszítőláncok hosszának változtatásával elérhető, hogy a vízszintes síkban megvalósuljon ez a feltétel.

A felső támasztórúd és az alsó vonókarok síkja a PFV függőleges pillanatnyi forgáspontban találkoznak. Itt érvényesül az erőgép vonóereje. Javasolt, hogy ez a pont vontatáskor a traktor hosszanti középvonalában legyen.

A karok hosszának csavarorsóval való változtatásával a vontatás és munkavégzés során jelentkező erők pillanatnyi forgáspontja áthelyezhető. Így a vontatás közben fellépő erők kiegyensúlyozódnak.

\subsection{A függesztett ágyeke és a ráható erők}

Az ágyeke a talaj forgatását biztosító munkagép. Munkája közben függőlegesen és vízszintesen kivágja a talajt, megemeli és jobb oldalra fordítja, elszállítva a talajt eredeti helyéről.

$\mathrm{Az}$ eke akkor dolgozik helyesen, ha az ekevasak párhuzamosak a talajfelszínnel, mindegyik ekevas ugyanabban a mélységben dolgozik. Ezt a

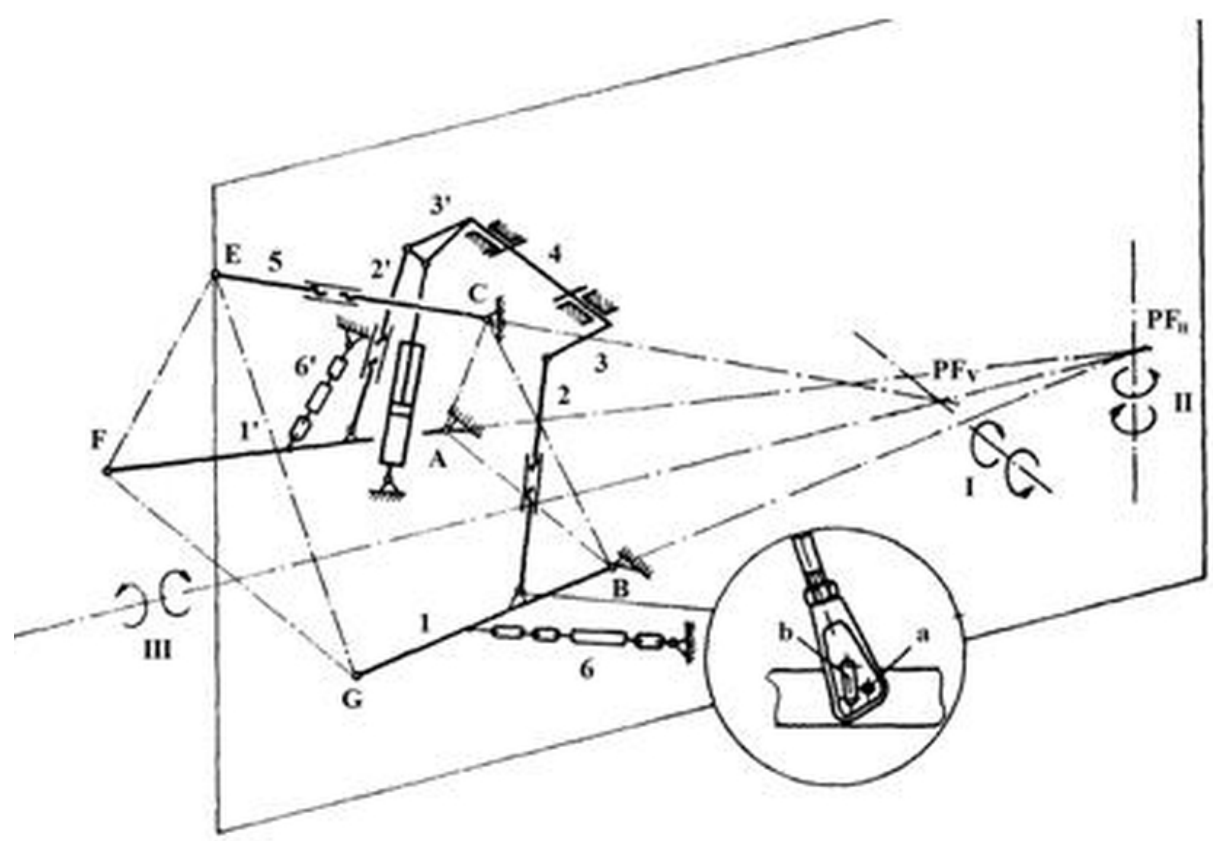

2. ábra. Hárompont-függesztő berendezés mechanizmusa [1] 
hárompont-függesztő berendezés megfelelő beállításával érjük el.

Az eketesten jelentkező erők (3.ábra):

$$
\underline{\boldsymbol{F}}=\left[\begin{array}{c}
F_{x} \\
F_{y} \\
F_{z}
\end{array}\right]=\left[\begin{array}{c}
-k_{0} \cdot a \cdot b \cdot n \\
F_{x} \operatorname{tg} \alpha \\
-F_{x} \operatorname{tg} \beta
\end{array}\right]
$$
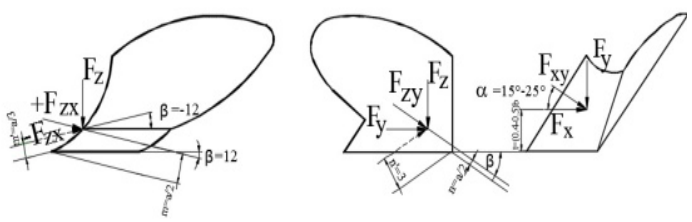

3. ábra. Az eketestre ható erők [2]

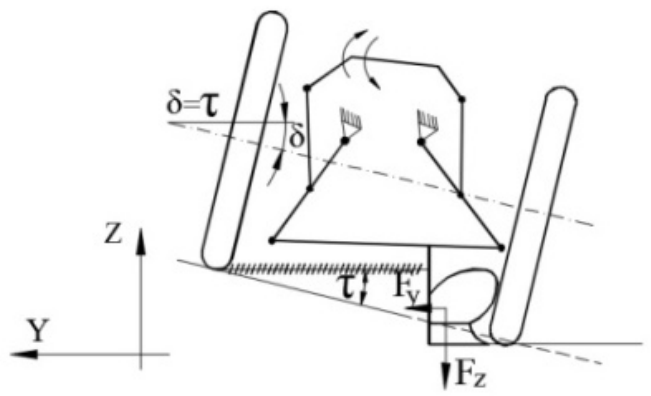

4. ábra. Eketest és erőgép helyzete szántás során
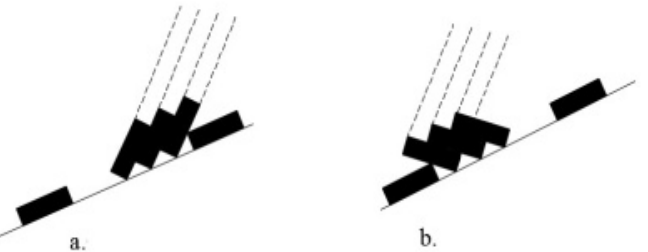

5. ábra. Barázdaátfordítás esetei rétegvonal menti szántás esetén: a) barázda emelkedőre borítása, b) barázda lejtőre borítása

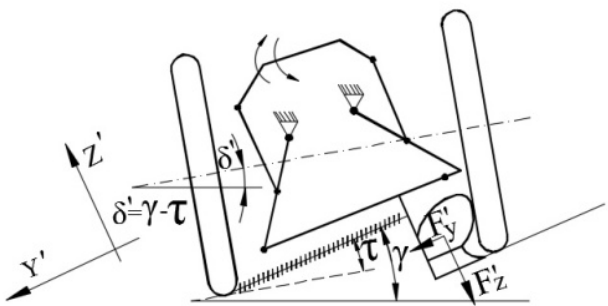

6. ábra. Gépcsoport helyzete barázda emelkedöre borítása során ahol: $k_{o}$ a talaj fajlagos ellenállása $\left[\mathrm{N} / \mathrm{m}^{2}\right] ; a$ a szántás mélysége [m]; $b$ az eke munkaszélessége [m]; $\alpha, \beta$ a kormánylemez helyzetszögei [].

Szántás közben az erőgép jobb oldali kerekei az előző fogásban kiemelt barázda helyén haladnak, emiatt egy $\delta$ dőlésszög jellemzi az erőgép tengelyét. Ezt a dőlésszöget sík területen a kerekek helyzete határozza meg (4. ábra).

\section{A függesztett ágyeke rétegvonal men- ti üzemeltetésének sajátosságai}

Az ágyeke munka közben összeszántja vagy szétszántja a barázdákat. Így a rétegvonal menti szántás során az eke a barázdát felfelé, az emelkedőre fordítja, míg a következő fogásban az eke a barázdát lefelé, a lejtőre fordítja (5. ábra). A csapadék jobb elraktározása és a talajerózió csökkentése érdekében a barázdák fordítása felfelé, az emelkedőre javasolt. A barázdák csak emelkedőre való borítása sok üresjárattal valósítható meg, emiatt elkerülhetetlen a lejtőre borítás is.

\subsection{Matematikai modellek meghatározása}

\subsubsection{Az eketesten jelentkező talajellenállások modellezése}

Az erőgép helyzete a rétegvonal menti szántásnál módosul, így a tengely $\delta$ dőlésszöge is módosul.

Mivel az eke a $\gamma$ szögű emelkedő rétegvonala mentén dolgozik, a barázda felfelé és lefelé borításánál az eketesten megjelenő talajellenállás is változik. Ezt a koordináta-rendszer elforgatásával számszerüsítjük, [3], [4]. Az elfordítást leíró koordináta-rendszer szabadon választható, a legegyszerűbb úgy tekinteni, hogy az eketestek az $O X$ tengely mentén elfordulnak a $\delta$ 'és $\delta$ ” dőlésszögekkel, (6. ábra és 7. ábra).

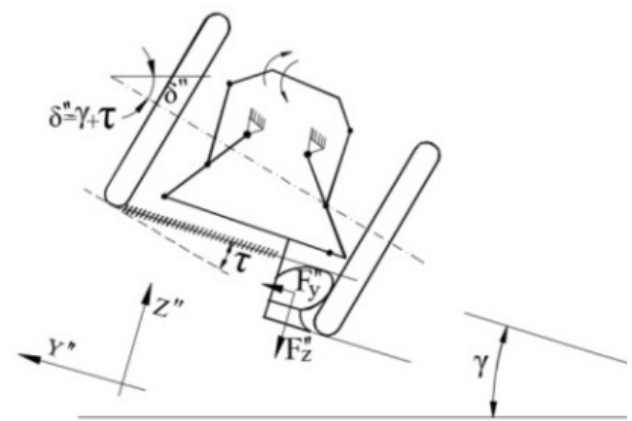

7. ábra. Gépcsoport helyzete barázda lejtöre forgatása során 
Az eke emelkedőre forgatásakor a 6. ábrán látható erőjáték keletkezik:

A transzformáció homogén mátrixa, Mx’ a következő:

$$
\boldsymbol{M}_{\boldsymbol{x}}{ }^{\prime}=\left[\begin{array}{cccc}
1 & 0 & 0 & 0 \\
0 & \cos \delta^{\prime} & -\sin \delta^{\prime} & 0 \\
0 & \sin \delta^{\prime} & \cos \delta^{\prime} & 0 \\
0 & 0 & 0 & 1
\end{array}\right]
$$

ahol: $\delta$ ' az emelkedőre borítás során a tengely dőlésszöge. Értéke az (3) összefüggéssel számolható:

$$
\delta^{\prime}=\tau-\gamma,
$$

Az eketestekre ható kényszererők új értékeket vesznek fel, melyeket az alábbi mátrixtranszformációval számolunk:

$$
\boldsymbol{F}^{\prime}=\boldsymbol{L}_{\boldsymbol{x}}{ }^{\prime} \cdot \boldsymbol{F}
$$

ahol $L_{x}$ ' az $M_{x}$ ' mátrix forgató almátrixa,

$$
\underline{\boldsymbol{F}}^{\prime}=\left[\begin{array}{c}
F_{x}^{\prime} \\
F_{y}^{\prime} \\
F_{z}^{\prime}
\end{array}\right]=\left[\begin{array}{c}
F_{x} \\
F_{y} \cos \delta^{\prime}-F_{z} \sin \delta^{\prime} \\
F_{y} \sin \delta^{\prime}+F_{z} \cos \delta^{\prime}
\end{array}\right] .
$$

Az eke lejtőre forgatás során a 7. ábrán látható. A transzformáció homogén mátrixa ebben az esetben $\mathbf{M}_{\mathrm{x}}$ ”:

$$
\boldsymbol{M}_{\boldsymbol{x}}{ }^{\prime \prime}=\left[\begin{array}{cccc}
1 & 0 & 0 & 0 \\
0 & \cos \delta^{\prime \prime} & \sin \delta^{\prime \prime} & 0 \\
0 & -\sin \delta^{\prime \prime} & \cos \delta^{\prime \prime} & 0 \\
0 & 0 & 0 & 1
\end{array}\right]
$$

ahol: $\delta$ ” a lejtőre borítás során, a tengelyen jelentkező dőlésszög. Értéke a (7) összefüggéssel számolható.

$$
\delta^{\prime \prime}=\tau+\gamma \text {. }
$$

Az eketestekre ható kényszererők új értékei:

$$
\boldsymbol{F}^{\prime \prime}=\boldsymbol{L}^{\prime \prime} \cdot \boldsymbol{F} \text {, }
$$

ahol $\mathrm{L}_{\mathrm{x}}$ ” az $\mathrm{M}_{\mathrm{x}}$ ” mátrix forgató almátrixa,

$$
\underline{\boldsymbol{F}}^{\prime \prime}=\left[\begin{array}{c}
F^{\prime \prime}{ }_{x} \\
F^{\prime \prime}{ }_{y} \\
F^{\prime \prime}{ }_{z}
\end{array}\right]=\left[\begin{array}{c}
F_{x} \\
F_{y} \cos \delta^{\prime \prime}+F_{z} \sin \delta^{\prime} \\
-F_{y} \sin \delta^{\prime \prime}+F_{z} \cos \delta^{\prime \prime}
\end{array}\right] .
$$

\subsubsection{Nyomatékmodellek meghatározása}

Amint az (5) és (9) összefüggések mutatják, a rétegvonal menti mozgás az eredeti beállításhoz képest megváltozott nagyságú oldalirányú erőket jelent, emiatt a síkfelületre állított eke $P F_{H}$ vízszintes pillanatnyi forgáspontjában nyomaték ébred.

A nyomatékegyenletet az erőgép hátsó tengelyének $O$-val jelzett középpontjára írjuk, mert erre ismertek az egyenletben használandó koordináták. $M$ ’ az emelkedőre borításnál jelentkező nyo-



8. ábra. A gépcsoporton jelentkezö erők az emelkedőre forgatáskor

b



9. ábra. A gépcsoporton jelentkező erők a lejtőre forgatáskor 
maték a pillanatnyi forgáspontban. A nyomaték irányát a gyakorlati tapasztalat alapján feltételeztük (8. ábra).

$x_{G} G \sin \delta^{\prime}+F_{x} y_{G}+F_{y}^{\prime} x_{G}-x_{T} G_{T} \sin \delta^{\prime}-M^{\prime}=0$,

ahol: $\left(x_{G}, y_{G}\right)$ az eke tömegközéppontjának koordinátái, [m]; $G$ az eke súlya, $[\mathrm{N}] ;\left(x_{T}, y_{T}\right)$ a traktor tömegközéppontjának koordinátái, [m]; $G_{T}$ a traktor súlya, [N].

$$
M^{\prime}=x_{G} G \sin \delta^{\prime}+F_{x} y_{G}+F_{y}^{\prime} x_{G}-x_{T} G_{T} \sin \delta^{\prime}
$$

A barázda lejtőre való borítása során az erők a PFH vízszintes pillanatnyi forgáspontban nyomatékot hoznak létre, amely irányát a tapasztalt jelenségek alapján adtuk meg és a 9. ábrán szemléltettük.

$$
-x_{G} G \sin \delta^{\prime \prime}+F_{x} y_{G}+F_{y}^{\prime \prime} x_{G}+x_{T} G_{T} \sin \delta^{\prime \prime}-M^{\prime \prime}=0
$$

$$
M^{\prime \prime}=-x_{G} G \sin \delta^{\prime \prime}+F_{x} y_{G}+F_{y}^{\prime \prime} x_{G}+x_{T} G_{T} \sin \delta^{\prime \prime}
$$

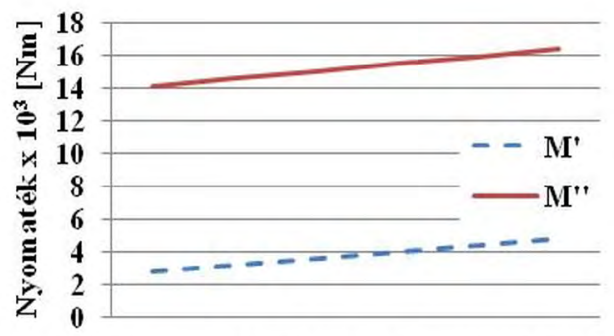

\section{$\begin{array}{llllll}0,2 & 0,21 & 0,22 & 0,23 & 0,24 & 0,25\end{array}$ $a$, munkamélység [m]}

10. ábra. Szántási mélység hatása a nyomatékértékekre
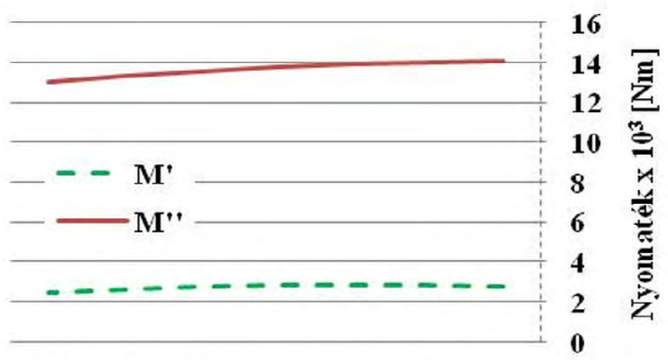

$\begin{array}{llllllll}0,6 & 0,65 & 0,7 & 0,75 & 0,8 & 0,85 & 0,9 & \text { b [m] }\end{array}$

11. ábra. Szántási szélesség hatása a nyomatékértékekre
A jelenséget magyarázó forgatóhatások az eke és az erőgép súlyától, és közvetve a munkamélységtől és a munkaszélességtől függnek (11), (13):

$$
\begin{gathered}
M^{\prime}=f\left(G, G_{T}, y_{G}, F^{\prime}{ }_{y}, F_{x}\right)=f\left(G, G_{T}, a, b\right) \\
M^{\prime \prime}=f\left(G, G_{T}, y_{G}, F^{\prime \prime}{ }_{y}, F_{x}\right)=f\left(G, G_{T}, a, b\right)
\end{gathered}
$$

\subsection{A jelenség elemzése}

A matematikai modellek alapján ábrázoltuk a tanulmányozott két esetben a nyomatékok alakulását a munkamélység és munkaszélesség függvényében (10. ábra, 11. ábra).

A használt adatok a PP3-30 eke méretei: $\mathrm{b}=3 \times 0,3 \mathrm{~m}$; súlya $\mathrm{G}=5000 \mathrm{~N}$; az eke tömegközéppontjának koordinátái: $\mathrm{x}_{\mathrm{G}}=1,7 \mathrm{~m}, \mathrm{y}_{\mathrm{G}}=0,3 \mathrm{~m}$. Fajlagos talajellenállás szántásnál középkötött talajon $\mathrm{k}_{\mathrm{o}}=50000 \mathrm{~N} / \mathrm{m}^{2}$-nek tekinthető [1]. Az erőgép tömegét 3500 kg-nak, az erőgép tömegközéppontjának koordinátái $\mathrm{x}_{\mathrm{T}}=0,5 \mathrm{~m}, \mathrm{y}_{\mathrm{T}}=0 \mathrm{~m}$, a lejtő szögét $30^{\circ}$-osnak tekintjük. Szakirodalmi utalások alapján [2] $\mathrm{F}_{\mathrm{y}} \approx 0,33 \mathrm{~F}_{\mathrm{x}}, \mathrm{F}_{\mathrm{z}} \approx 0,2 \mathrm{Fx}$.

\section{Következtetések}

A barázda emelkedőre borítása során az erőgép járása nyugodtabb, az erőgép vezetője jól tartja az irányt, mert az erőgép jobb oldali kerekei megtámaszkodhatnak a barázdafalon, így a keletkező nyomaték egy részét a barázdafal felveszi.

A barázda lejtőre való borítása során nagyobb forgatóhatás jelentkezik. Az erőgép jobb oldali kerekei nem támaszkodnak a barázdafalon, az így keletkező nyomatékot teljes egészében a kormányszerkezet veszi fel, emiatt az erőgép vezetője nehezen tartja az irányt.

A munkamélység növelése mindkét esetben növeli a keletkező nyomatékokat. A munkaszélesség csökkentése csökkenti a keletkező nyomatékok nagyságát rétegvonal menti szántás során.

A tapasztalt jelenségek felhívják a figyelmet az ekék pontos beállításának fontosságára.

A matematikai modellek magyarázzák a jelenséget, alkalmasak további kutatásokra.

\section{Szakirodalmi hivatkozások}

[1] Ormenișan A. N.: Theoretical and Experimental Research Concerning the Influence of Automatic Control Systems of the Tractor Linkage Mechanisms on the Dynamics and Energetics of Ploughing Units, UTBv, 2014. 19-37. (letöltve 2018. január 24.)

http://old.unitbv.ro/Portals/31/Sustineri\%20de\%20 doctorat/Rezumate2014/OrmenisanAlexe.pdf 
[2] Szendrő P.: Mezőgazdasági gépszerkezettan. Mezőgazdasági Kiadó, Budapest, 2000. 79-82.

[3] Máté, M.: Müszaki mechanika - kinematika. EME Kiadó, Kolozsvár, 2010. 155-163.

[4] Tolvaly-Roșca F., Papp I.: Kinematic Analysis of 2 DoF Spherical Mechanism Applying Constraint Equations. MACRo, Marosvásárhely, Románia, 2015. 235-240. (letöltve 2018. január 24.)

https://www.degruyter.com/downloadpdf/j/ macro.2015.1.issue-1/macro-2015-0023/macro-2015-0023.pdf 